\title{
Production Optimization by USING OF GENETIC ALGORITHMS AND SIMULATION MODEL
}

\author{
SCHREIBER, P.; VAZAN, P.; TANUSKA, P. \& MORAVCIK, O.
}

Abstract: The paper presents the way how it is possible to combine the behaviour of simulation model of production system and its optimization by genetic algorithms considering the fulfilment of quantitative production goals in defined conditions. The objective function expresses the production costs (it is additive nonlinear function with more variables). The constrains are: flow time, capacity utilization and number of finished parts. The mathematical model is either very complicated for analytical solution, or it is not explicitly formulateble. Although optimizing methods are implemented in simulators, often they are not effective enough. The genetic algorithms seem to be a simply alternative for the solution of this problem.

Key words: manufacturing, goals optimization, simulation, genetic algorithms
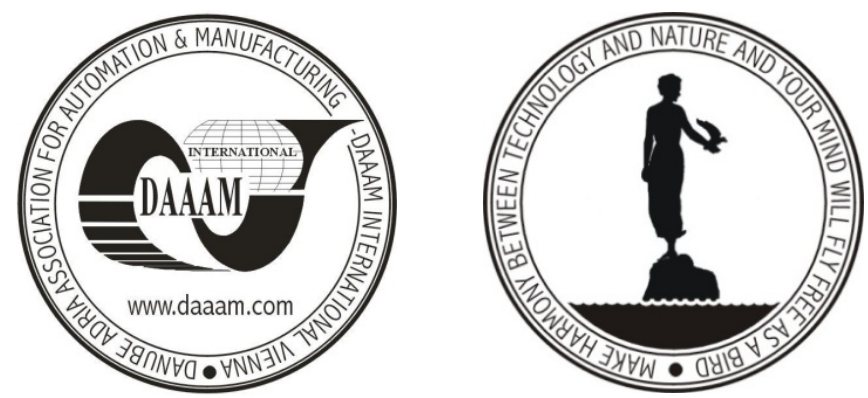

Authors' data: doc. Ing. PhD. Schreiber, $\mathrm{P}[$ eter]; doc. Ing. PhD. Vazan, P[avel]; doc. Ing. PhD. Tanuska, P[avol]; Dipl. Prof. Ing. Moravcik, O[liver], Faculty of Material Science and Technlogy, Slovak University of Technology in Trnava, Paulinska 16, 91724 Trnava, Slovakia, peter.schreiber@stuba.sk, pavel.vazan@stuba.sk,pavol.tanuska@stuba.sk, oliver.moravcik@stuba.sk

This Publication has to be referred as: Schreiber, $\mathrm{P}$ [eter]; Vazan, $\mathrm{P}$ [avel]; Tanuska, $\mathrm{P}$ [avol] \& Moravcik, O[liver] (2009). Production Optimization by Using of Genetic Algorithms and Simulation Model, Chapter 19 in DAAAM International Scientific Book 2009, pp. 169-176, B. Katalinic (Ed.), Published by DAAAM International, ISBN 978-3-901509-69-8, ISSN 1726-9687, Vienna, Austria

DOI: $10.2507 /$ daaam.scibook.2009.19 